\title{
Perforated Patch Clamp in Non-Neuronal Cells, the Model of Mammalian Sperm Cells
}

\author{
Jorge Parodi ${ }^{1}$ and Ataúlfo Martínez-Torres ${ }^{2}$ \\ ${ }^{1}$ Escuela de Medicina Veterinaria, Facultad de Recursos Naturales, \\ Núcleo de Producción Alimentaria, Universidad Católica de Temuco, Temuco \\ ${ }^{2}$ Departamento de Neurobiología Celular y Molecular, Laboratorio de \\ Neurobiología Molecular y Celular, Instituto de Neurobiología, \\ Campus UNAM-Juriquilla, Querétaro, \\ ${ }^{1}$ Chile \\ ${ }^{2}$ México
}

\section{Introduction}

This chapter deals with the steps required to obtain perforated patch-clamp recordings from mammalian sperm cells. (in spite of the fact that these cells) In spite of the fact that these cells are not electrically excitable, they possess a number of conductances due to their expression of ion channels and even neurotransmitter-gated ion-channels, many of which remain to be explored functionally and structurally. Detailed methods for obtaining cells suitable for electrophysiological recordings and protocols to perform patch-clamp recordings are outlined in the text.

\section{Perforated patch recording}

Classic whole-cell recordings (Hamill et al., 1981) could dilute or wash out crucial elements of intracellular signaling cascades and even completely replace the intracellular milieu. In this technique, occasionally it is necessary to apply negative pressure to break down the plasma membrane and allow the continuity between the recording electrode and the cytoplasm. With the advent of perforated patch recordings in neurons (Ebihara et al., 1995), a compromise between good electrical signals and preservation of the intracellular milieu became available, and importantly for this review, the method is also suitable for nonneuronal cells.

The principle of perforated patch clamping relies on the action of drugs, such as classic antifungals (Akaike and Harata, 1994; Akaike, 1996). These molecules form holes in the plasma membrane, which are permeable to ions but do not allow the traffic of larger molecules. One of the most common molecules used in this protocol is nystatin, and others such as gramicidin and amphotericin B are also widely used. One of the key elements to obtain successful patch recordings is the proper application of the perforating drug; during this critical period of time is necessary to control the right time of drug application must be carefully controlled, because if the drug is added before the electrode forms a tight gigaseal 
with the plasma membrane, the membrane could be irreversible damaged. Depending on the cell type, some time should be taken to make the seal: a significant time interval (around 35 minutes) should be allowed for seal formation to ensure that the perforating drug is exposed only to the area of the plasma membrane that forms the seal with the recording electrode (Ueno et al., 1992; Lippiat, 2008). The most practical method to induce the perforated patch is by filling the pipette tip with intracellular recording solution containing the perforating drug. The drug will gradually diffuse to the membrane, and development of the whole-cell current response can be monitored.

\section{Procedure}

\subsection{The sperm cell patch-clamp}

The main tool used to investigate the characteristics and distribution of ion channels in the plasma membrane is the "patch-clamp" technique first described by Neher and Sakmann in 1976 and modified by Hamill in 1981 . However, at that point patch-clamp recordings were of limited use in electrophysiological studies in other complex cells like cells like the mammalian sperm due to its shape and small size (Linares-Hernandez et al., 1998; Gorelik et al., 2002).

To deal with this technical problem several alternatives have been devised. Some researchers determined that high resistance seals with hyposmotic solutions are ideal, especially for the sea urchin sperm; however, the cell-attached configuration and high resistance seals last only for a few minutes, making it difficult to record the currents generated by ion channels (Sanchez et al., 2001). The second alternative is the electrophysiological study of ion channels in the membranes of spermatogonial cells in late stages of development (Munoz-Garay et al., 2001). Technically, the procedure is easier in these cells than in mature sperm because the spermatogonial cells are much larger (Arnoult et al., 1996; Santi et al., 1996; Darszon et al., 1999). The plasma membrane of spermatogonial cells is functionally and structurally similar to the membrane of mature sperm, but there are many differences in types and cell distribution of ion channels (Serrano et al., 1999). The third alternative is the reconstitution of ion channels in artificial lipid bilayers; however, this technique removes the ion-channels from their natural lipidic environment and therefore, their biophysical properties are not precisely the same as in the cell plasma membrane (Lievano et al., 1990). The probability of obtaining a high resistance seal of the sperm head by microscopy using perforated patch clamp is about $45 \%$; this is 15 times greater than the probability reported in studies using conventional "patch-clamp". In our personal experience, a tight seal is successfully obtained in 1 out of 10 trials (Guerrero et al., 1987; Navarrete et al., 2010). The time interval of the cell-attached recordings averages $35 \mathrm{~min}$, which suffices to obtain many valuable biophysical data (Marconi et al., 2008; Navarrete et al., 2010).

\subsubsection{Sperm selection}

The sperm selection method chosen is "swim up" (WHO, 1999). Briefly, the sample is collected by manual manipulation and incubated for $40 \mathrm{~min}$ at $37^{\circ} \mathrm{C}$ to liquefy the semen. Then $1 \mathrm{ml}$ of semen is suspended in a Falcon tube with $4 \mathrm{ml}$ of medium (DMEM), spun down at $1200 \mathrm{rpm}(200 \mathrm{~g})$ for $10 \mathrm{~min}$, and the supernatant removed. The pellet is dissolved in $4 \mathrm{ml}$ of medium and centrifuged for $5 \mathrm{~min}$ at $1200 \mathrm{rpm}(200 \mathrm{~g})$. The supernatant is 
removed and the pellet is incubated with $1 \mathrm{ml}$ of medium for $1 \mathrm{~h}$ at $37^{\circ} \mathrm{C}$ tilted at $45^{\circ}$. Finally, the upper portion of the suspension that is rich in motile sperms is collected (Navarrete et al., 2010).

\section{2 "Perforated patch-clamp" in mammalian sperm}

An aliquot $(200 \mu \mathrm{l})$ of the upper portion of sperm suspension is incubated with $1800 \mu \mathrm{l}$ of hyposmotic medium (see section Preparation of solutions) for $20 \mathrm{~min}$, then centrifuged at $1200 \mathrm{rpm}(200 \mathrm{~g})$ for $5 \mathrm{~min}$. The supernatant is discarded, and the pellet is resuspended in 3 $\mathrm{ml}$ of bath solution $(150 \mathrm{mM} \mathrm{KCl})$ and centrifuged at $1200 \mathrm{rpm}(200 \mathrm{~g})$ for $5 \mathrm{~min}$. After removing the supernatant, the pellet is resuspended in $2 \mathrm{ml}$ of bathing solution (see section Preparation of solutions). Subsequently $1 \mathrm{ml}$ of suspension is placed in the "patch clamp" recording chamber previously prepared with Pegotina ${ }^{\circledR}$ (peptides with adherent properties, US patent 20110062047) or another suitable adhesive, such as poly-lysine, laminin etc. The sperm suspension is placed in the chamber and left undisturbed for $10 \mathrm{~min}$ to secure the interaction and permit attachment of the cells, with the bioadhesive.

Micropipettes are made of borosilicate capillaries (Sutter Instrument Co., CA, USA is one of several options in a vertical or horizontal puller). The level of stretching and heat is adjusted to obtain a tip between $0.5 \mu \mathrm{m}$ and $1.5 \mu \mathrm{m}$ of diameter, and then the tip is heat polished.

A silver cylinder of $2 \mathrm{~mm}$ diameter and $3 \mathrm{~cm}$ long is used as reference electrode (Ag / $\mathrm{AgCl})$; previously bathed it is pretreated in a bath of sodium hypochlorite and placed in a polyethylene tube whose tip is shaped to form a fine point. Inside the tube is a bed of agar$\mathrm{KCl}(2 \%$ agar in $150 \mathrm{mM} \mathrm{KCl})$ to minimize the junction potential of the solution-electrode interface. One electrode is connected to a current-voltage converter "probe" and to the amplifier. A second electrode is a thin silver chloride wire inserted into the adapter micropipette "holder" and connected to the "probe". Through the "holder", positive pressure is applied to the pipette to prevent adhesion of particles and, in addition, negative pressure is essential to obtain high-resistance seals.

\section{3 "Cell attached" configuration}

The "patch clamp" is basically a piece of electric isolate to record unitary currents that flow through one or more ion channels present in a fragment of membrane set to a given potential by the researcher. To achieve a "patch clamp" it is necessary that the seal between the tip of the micropipette and the membrane has a resistance on the order of G $\Omega$. Initially, the micropipette inserted into the "holder" will be immersed in the solution, and the resistance is determined through a current, monitored in a data acquisition system, in response to a rectangular pulse voltage of $5 \mathrm{mV}, 110 \mathrm{~ms}$, and $5 \mathrm{~Hz}$ generated by the same amplifier. Depending on the diameter of the pipette, the resistance should be between 6 and $12 \mathrm{M} \Omega$ when measured in symmetrical solution concentrations of $150 \mathrm{mM} \mathrm{KCl}$. The micropipette is then positioned with a micromanipulator in an inverted optical microscope and pressed against the surface of the sperm membrane; this maneuver leads to an increase of resistance.

By applying negative pressure in the pipette, the resistance and formation of a seal will be reached: the resistance will increase and a seal will be formed, then capacitive current spikes 
will appear at the beginning and end of the voltage pulse. These peaks are minimized by the capacitive compensation circuit before beginning the experiment. The configuration with the pipette attached to the surface of the plasma membrane is called the "cell attached" (Figure 1) and allows the recording of unitary currents through the electrically isolated "patch" at the tip of the pipette. This configuration is also suitable to evaluate the current response to changes in the perfusion medium.

\subsection{Perforating the plasma membrane.}

The antifungals must be dissolved in their appropriate solvent (DMSO, ethanol) and then diluted in the intracellular recording solution. The pipette tip is filled with intracellular solution using different approaches, either a syringe with a long, fine needle, or by capillarity, or even with a syringe whose tip has been melted. Typical concentrations for nystatin or amphotericin B are 5-20 mgr/ml, from a 1000-fold stock (Mistry and Hablitz, 1990; Akaike and Harata, 1994; Rhee et al., 1994). After the formation of the gigaseal the patch is left intact, and the current response to test pulses is monitored. If all is well, the cell capacitance should be evident after $10 \mathrm{~min}$, with decreasing access resistance (faster capacitive transient). After 20-30 min the capacitive transient should be stable, and the experiment can begin (Figure 1).

\subsection{Final step, perforated patch-clamp}

When the cell-attached configuration is reached, some time is needed to see changes in the capacitive peak, and to observe the openings of the membrane (Figure 1). When a change is detected in the capacitive peak, as evidenced by modifications in the decay slope (figure 1, arrows), it indicates that the seal has been opened. The velocity of the event depends on the concentration of the perforating molecules, and some time is required to fully calibrate the system. No more steps are needed after the cell is attached (Parodi et al., 2010; Sepulveda et al., 2010).

Yet another critical factor to achieve perforated patch recordings is the time that the molecules in the intracellular solution take to form a strong gigaseal. High concentrations of the molecule can be toxic and induce alterations in the recordings, whereas low concentrations may take longer to form the gigaseal (and affect the viability of the cells), reaching times of declining cell viability. To assure that the gigaseal is properly developing, the passive properties of the membrane should be continually monitored.

\subsection{Quality control}

Below, we present a list of criteria to get proper whole-cell recordings:

1. The seal resistance must be higher than $1 \mathrm{G}$ at the beginning of the experiment.

2. The series resistance must be lower than $20 \mathrm{M} \Omega$ and stay that way throughout the recording. A high series resistance is undesirable because the voltage clamp of the cell membrane is adversely affected.

3. The time constant $(\tau)$ of the capacitive transient in the current response should be proportional to the series resistance, so a slow capacitive transient is a bad sign. A common problem is gradual resealing of the patch after breakthrough, apparently by spreading of the capacitive transients. 

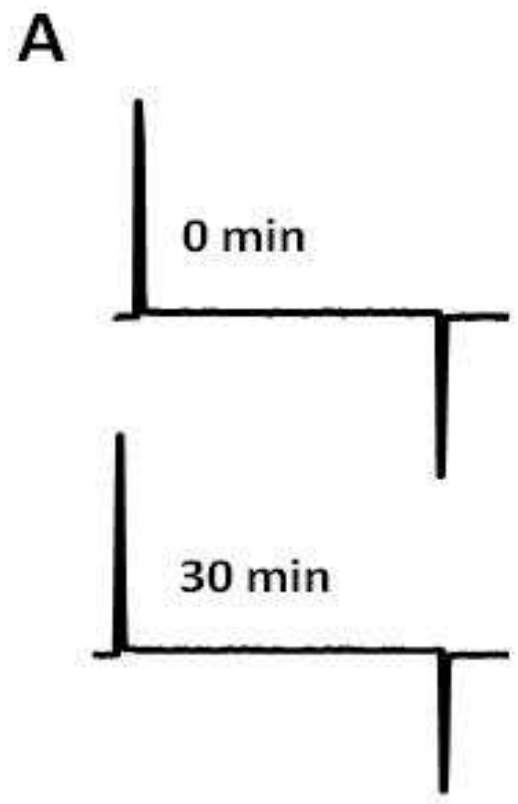

B

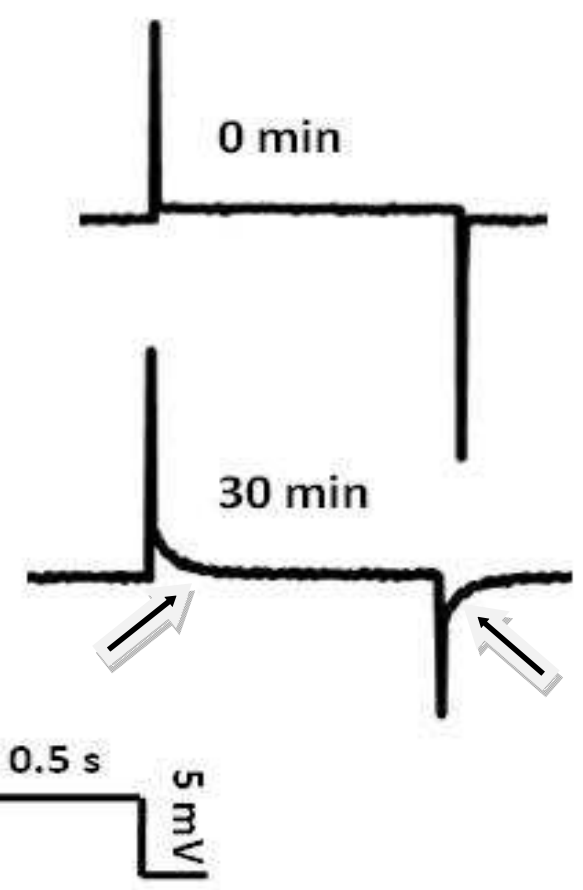

Fig. 1. Establishment of perforated patch mature bovine sperm cells. A. A membrane seal without perforating molecules. The lower recording shows the cell before applying negative pressure in the pipette. B. shows the time course of seal formation with perforating agent. The gigaseal formed $30 \mathrm{~min}$ after inclusion of the drug (lower trace). The arrow indicated, the changes in the slope, when the seal are open.

4. The membrane potential must be more negative than $-50 \mathrm{mV}$ if a high-potassium intracellular solution is used. This value varies depending on the cell type; thus, laboratory conditions for these which just the potential parameters should be controlled.

5. Cell capacitance and resistance must be stable.

\subsection{General conclusions and applications}

The perforated patch-clamp technique has allowed the study of functional properties in several cell models. In particular, the physiology of sperm has been widely studied by Dr. Darszon's group in Mexico. Using this experimental approach along with other techniques of cell biology, this group described the presence and function of CatSper channels in mammalian sperm cells and showed their importance in basic functional processes such as sperm "capacitation" (Darszon et al., 1999) 
Dr. Romero's group in Chile continues to explore other ion currents present in sperm cells and has described outward potassium currents of the Kv type (Marconi et al., 2008). Using this approach, the same group recently showed that this current was sensitive to peptides isolated from spider venom (Parodi et al., 2010) and that this modulation generates functional changes that alter the acrosome reaction of the sperm (Navarrete et al., 2010) and lead to changes in the relationship between sperm and oviductal cells (Navarrete et al., 2011, in press Andrology). Recently, this information was reviewed and suggestions raised that indicate that CatSper channels modulate several other cellular functions in sperm cells

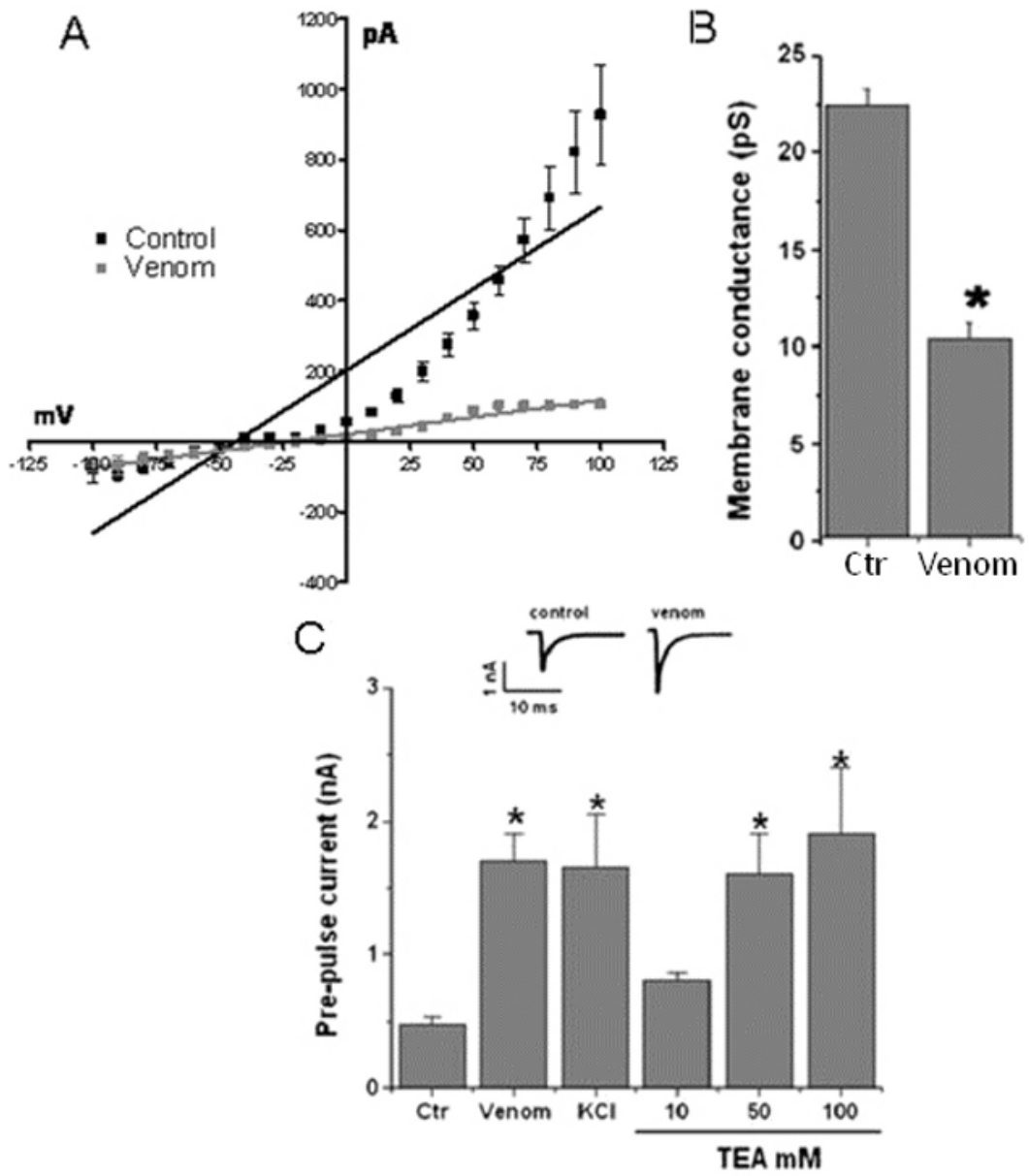

Fig. 2. Effects of Chilean L. mactans venom extract on electrophysiological properties of mammalian spermatozoa. A. Current-voltage relations in the absence or presence of 7.5 $\mu \mathrm{g} / \mathrm{mL}$ venom. B. Membrane conductance of sperm exposed to the venom. C. The effect of different conditions on pre-pulse currents. The sperm cells were held in the whole-cell configuration, perforated patch-clamp. The bars are means \pm SD of 6 different experiments, * indicates significant difference, $\mathrm{p}<0.05$. Modified, from Parodi et al., 2010. 
(Navarrete et al., 2011). A sample recording obtained by the perforated patch-clamp technique in sperm is observed in figure 2, in which the typical $\mathrm{Kv}$ current is evidenced.

A new approach to study the impact of toxic agents was devised by Dr. Aguayo's group in Chile, who modified the intracellular recording solutions to introduce aggregates of $\beta$ amyloid, a peptide highly accumulated in the brains of Alzheimer's disease patients. Following seal formation, as we have described above, and without the use of a traditional penetrating agent, this group suggested that $\beta$-amyloid induces pores in the plasma membrane, thus allowing perforated patch-clamp recordings in several cell types (Sepulveda et al., 2010) and US Patent 02908-2007.

\section{Preparation of solutions}

To prepare solution with BAPTA tetracesium salt* in internal solution with $\mathrm{CsCl}$ :

1. Pour filtered solution into $50-\mathrm{ml}$ beaker.

2. Add $0.502 \mathrm{~g}$ BAPTA for $50 \mathrm{ml}$ of $10 \mathrm{mM}$ solution (1.004 for $100 \mathrm{ml})$.

3. Adjust $\mathrm{pH}$ to 7.4 with $\mathrm{CsOH}$.

4. Measure osmolarity.

5. Adjust osmolarity to $290-310$ with sucrose $(\approx 0.5 \mathrm{~g}$ for $50 \mathrm{ml})$.

6. Pour into $50-\mathrm{ml}$ flask and complete to $50 \mathrm{ml}$ with ultra pure water.

7. Store as $5-\mathrm{ml}$ aliquots.

* A cell-impermeant chelator, highly selective for $\mathrm{Ca}^{2+}$ over $\mathrm{Mg}^{2+}$

To prepare solution with EGTA in internal solution with $\mathrm{KCl}$ :

1. Pour filtered solution into $50-\mathrm{ml}$ beaker.

2. Add $0.3804 \mathrm{~g}$ EGTA (for $10 \mathrm{mM}$ ).

3. Adjust $\mathrm{pH}$ to 7.4 with $\mathrm{KOH}$.

4. Measure osmolarity and adjust to 290-310 with sucrose.

5. Pour into 50-ml flask and complete to $50 \mathrm{ml}$ with ultra pure water.

6. Aliquot, cover with aluminum foil, label, and put in freezer.

\section{PATCH CLAMP}

Internal Cesium Solution (without $\mathrm{Na}_{2} \underline{A T P}, 2 \mathrm{mM}$ )

\begin{tabular}{|c|c|c|c|c|}
\hline & $\underline{\mathrm{mM}}$ & $\underline{\mathrm{FW}}$ & $\mathrm{g} / 50 \mathrm{ml}$ & $\mathrm{g} / 100 \mathrm{ml}$ \\
\hline $\mathrm{CsCl}$ & 120 & 168.36 & 1.01 & 2.02 \\
\hline HEPES & 10 & 238.30 & 0.12 & 0.24 \\
\hline $\mathrm{MgCl}_{2} 6 \mathrm{H}_{2} \mathrm{O}$ & 4 & 203.31 & 0.04 & 0.08 \\
\hline
\end{tabular}

$\underline{\text { Internal Potassium Solution (without } \mathrm{Na}^{2} \mathrm{ATP}, 2 \mathrm{mM} \text { ) }}$

$\begin{array}{lrrrc} & \underline{\mathrm{mM}} & \underline{\mathrm{FW}} & \mathbf{g} / \mathbf{5 0 ~ \mathbf { ~ l }} & \mathrm{g} / 100 \mathrm{ml} \\ \mathrm{KCl} & 120 & 74.56 & \mathbf{0 . 4 5} & 0.89 \\ \mathrm{Hepes} & 10 & 238.30 & \mathbf{0 . 1 2} & 0.24 \\ \mathrm{MgCl}_{2} 6 \mathrm{H}_{2} \mathrm{O} & 4 & 203.31 & \mathbf{0 . 0 4} & 0.08\end{array}$




\section{External bathing solution}

$\begin{array}{lrccc} & \underline{\mathrm{mM}} & \underline{\mathrm{FW}} & \mathrm{g} / \mathbf{L T} & \mathrm{g} / 500 \mathrm{ml} \\ \mathrm{NaCl} & 140 & 58.5 & 190 & 4095 \\ \mathrm{KCl} & 5 & 74.6 & 373 & 186.5 \\ \mathrm{CaCl}_{2} & 1 & 112.2 & 112.2 & 56.1 \\ \mathrm{MgCl}_{2} & 1 & 95.5 & 95.5 & 47.75 \\ \mathrm{Hepes} & 10 & 238.3 & 2383 & 1191.5 \\ \text { Glucose } & 10 & 180 & 1800 & 900\end{array}$

External solution, hyposmotic

$\begin{array}{llcll} & \underline{\mathrm{mM}} & \underline{\mathrm{FW}} & \mathrm{g} / \mathbf{L T} & \mathrm{g} / 500 \mathrm{ml} \\ \mathrm{KCl} & 35 & 74.6 & 2611 & 1305.5 \\ \mathrm{Hepes} & 10 & 238.3 & 2383 & 1191.1\end{array}$

\section{Acknowledgments}

This work was partially supported by grants from CONACYT 101851 and UNAM-PAPIT 204806 (to AM-T and RM). J.P. is a postdoctoral fellow from CTIC-UNAM. JP has a travel grant from MECESUP - PUC/0708 of "Pontificia Universidad Catolica de Chile".

We are in debt to Dr. Dorothy Pless for editing the manuscript.

\section{References}

Akaike N (1996) Gramicidin perforated patch recording and intracellular chloride activity in excitable cells. Prog Biophys Mol Biol 65:251-264.

Akaike N, Harata N (1994) Nystatin perforated patch recording and its applications to analyses of intracellular mechanisms. Jpn J Physiol 44:433-473.

Arnoult C, Grunwald D, Villaz M (1996) Novel postfertilization inward Ca2+ current in ascidian eggs ensuring a calcium entry throughout meiosis. Dev Biol 174:322334.

Darszon A, Labarca P, Nishigaki T, Espinosa F (1999) Ion channels in sperm physiology. Physiol Rev 79:481-510.

Ebihara S, Shirato K, Harata N, Akaike N (1995) Gramicidin-perforated patch recording: GABA response in mammalian neurones with intact intracellular chloride. J Physiol 484 ( Pt 1):77-86.

Gorelik J, Gu Y, Spohr HA, Shevchuk AI, Lab MJ, Harding SE, Edwards CR, Whitaker M, Moss GW, Benton DC, Sanchez D, Darszon A, Vodyanoy I, Klenerman D, Korchev YE (2002) Ion channels in small cells and subcellular structures can be studied with a smart patch-clamp system. Biophys J 83:3296-3303.

Guerrero A, Sanchez JA, Darszon A (1987) Single-channel activity in sea urchin sperm revealed by the patch-clamp technique. FEBS Lett 220:295-298. 
Hamill OP, Marty A, Neher E, Sakmann B, Sigworth FJ (1981) Improved patch-clamp techniques for high-resolution current recording from cells and cell-free membrane patches. Pflugers Arch 391:85-100.

Lievano A, Vega-SaenzdeMiera EC, Darszon A (1990) Ca2+ channels from the sea urchin sperm plasma membrane. J Gen Physiol 95:273-296.

Linares-Hernandez L, Guzman-Grenfell AM, Hicks-Gomez JJ, Gonzalez-Martinez MT (1998) Voltage-dependent calcium influx in human sperm assessed by simultaneous optical detection of intracellular calcium and membrane potential. Biochim Biophys Acta 1372:1-12.

Lippiat JD (2008) Whole-cell recording using the perforated patch clamp technique. Methods Mol Biol 491:141-149.

Marconi M, Sanchez R, Ulrich H, Romero F (2008) Potassium current in mature bovine spermatozoa. Syst Biol Reprod Med 54:231-239.

Mistry DK, Hablitz JJ (1990) Nystatin-perforated patch recordings disclose NMDA-induced outward currents in cultured neocortical neurons. Brain Res 535:318-322.

Munoz-Garay C, De la Vega-Beltran JL, Delgado R, Labarca P, Felix R, Darszon A (2001) Inwardly rectifying $\mathrm{K}(+)$ channels in spermatogenic cells: functional expression and implication in sperm capacitation. Dev Biol 234:261-274.

Navarrete P, Ormeño D, Miranda A, Sánchez R, Romero R, Parodi J. (2011) Molecular characterization, electrophysiological and contraceptive effect of Chilean Latrodectus venom. International Journal of Morphology 29(3): 733-741.

Navarrete P, Martinez-Torres A, Gutierrez RS, Mejia FR, Parodi J (2010) Venom of the Chilean Latrodectus mactans alters bovine spermatozoa calcium and function by blocking the TEA-sensitive K(+) current. Syst Biol Reprod Med 56:303-310.

Neher E, Sakmann B (1976) Single-channel currents recorded from membrane of denervated frog muscle fibres. Nature 260:799-802.

Parodi J, Navarrete P, Marconi M, Gutierrez RS, Martinez-Torres A, Mejias FR (2010) Tetraethylammonium-sensitive $\mathrm{K}(+)$ current in the bovine spermatozoa and its blocking by the venom of the Chilean Latrodectus mactans. Syst Biol Reprod Med 56:37-43.

Rhee JS, Ebihara S, Akaike N (1994) Gramicidin perforated patch-clamp technique reveals glycine-gated outward chloride current in dissociated nucleus solitarii neurons of the rat. J Neurophysiol 72:1103-1108.

Sanchez D, Labarca P, Darszon A (2001) Sea urchin sperm cation-selective channels directly modulated by cAMP. FEBS Lett 503:111-115.

Santi CM, Darszon A, Hernandez-Cruz A (1996) A dihydropyridine-sensitive T-type Ca2+ current is the main Ca2+ current carrier in mouse primary spermatocytes. Am J Physiol 271:C1583-1593.

Sepulveda FJ, Parodi J, Peoples RW, Opazo C, Aguayo LG (2010) Synaptotoxicity of Alzheimer beta amyloid can be explained by its membrane perforating property. PLoS One 5:e11820.

Serrano CJ, Trevino CL, Felix R, Darszon A (1999) Voltage-dependent Ca(2+) channel subunit expression and immunolocalization in mouse spermatogenic cells and sperm. FEBS Lett 462:171-176. 
Ueno S, Ishibashi H, Akaike N (1992) Perforated-patch method reveals extracellular ATPinduced $\mathrm{K}+$ conductance in dissociated rat nucleus solitarii neurons. Brain Res 597:176-179. 


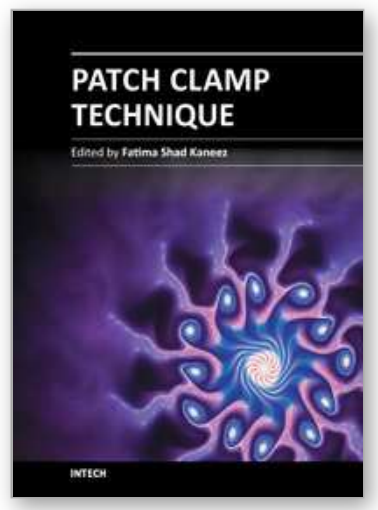

\author{
Patch Clamp Technique \\ Edited by Prof. Fatima Shad Kaneez
}

ISBN 978-953-51-0406-3

Hard cover, 356 pages

Publisher InTech

Published online 23, March, 2012

Published in print edition March, 2012

This book is a stimulating and interesting addition to the collected works on Patch clamp technique. Patch Clamping is an electrophysiological technique, which measures the electric current generated by a living cell, due to the movement of ions through the protein channels present in the cell membrane. The technique was developed by two German scientists, Erwin Neher and Bert Sakmann, who received the Nobel Prize in 1991 in Physiology for this innovative work. Patch clamp technique is used for measuring drug effect against a series of diseases and to find out the mechanism of diseases in animals and plants. It is also most useful in finding out the structure function activities of compounds and drugs, and most leading pharmaceutical companies used this technique for their drugs before bringing them for clinical trial. This book deals with the understanding of endogenous mechanisms of cells and their receptors as well as advantages of using this technique. It covers the basic principles and preparation types and also deals with the latest developments in the traditional patch clamp technique. Some chapters in this book take the technique to a next level of modulation and novel approach. This book will be of good value for students of physiology, neuroscience, cell biology and biophysics.

\title{
How to reference
}

In order to correctly reference this scholarly work, feel free to copy and paste the following:

Jorge Parodi and Ataúlfo Martínez-Torres (2012). Perforated Patch Clamp in Non-Neuronal Cells, the Model of Mammalian Sperm Cells, Patch Clamp Technique, Prof. Fatima Shad Kaneez (Ed.), ISBN: 978-953-51-04063, InTech, Available from: http://www.intechopen.com/books/patch-clamp-technique/perforated-patch-clampin-non-neuronal-cells-the-model-of-mammalian-sperm-cells

\section{INTECH}

open science / open minds

\section{InTech Europe}

University Campus STeP Ri

Slavka Krautzeka 83/A

51000 Rijeka, Croatia

Phone: +385 (51) 770447

Fax: +385 (51) 686166

www.intechopen.com

\section{InTech China}

Unit 405, Office Block, Hotel Equatorial Shanghai

No.65, Yan An Road (West), Shanghai, 200040, China 中国上海市延安西路65号上海国际贵都大饭店办公楼 405 单元

Phone: +86-21-62489820

Fax: $+86-21-62489821$ 
(C) 2012 The Author(s). Licensee IntechOpen. This is an open access article distributed under the terms of the Creative Commons Attribution 3.0 License, which permits unrestricted use, distribution, and reproduction in any medium, provided the original work is properly cited. 